DS PROTEOME SCIENCE

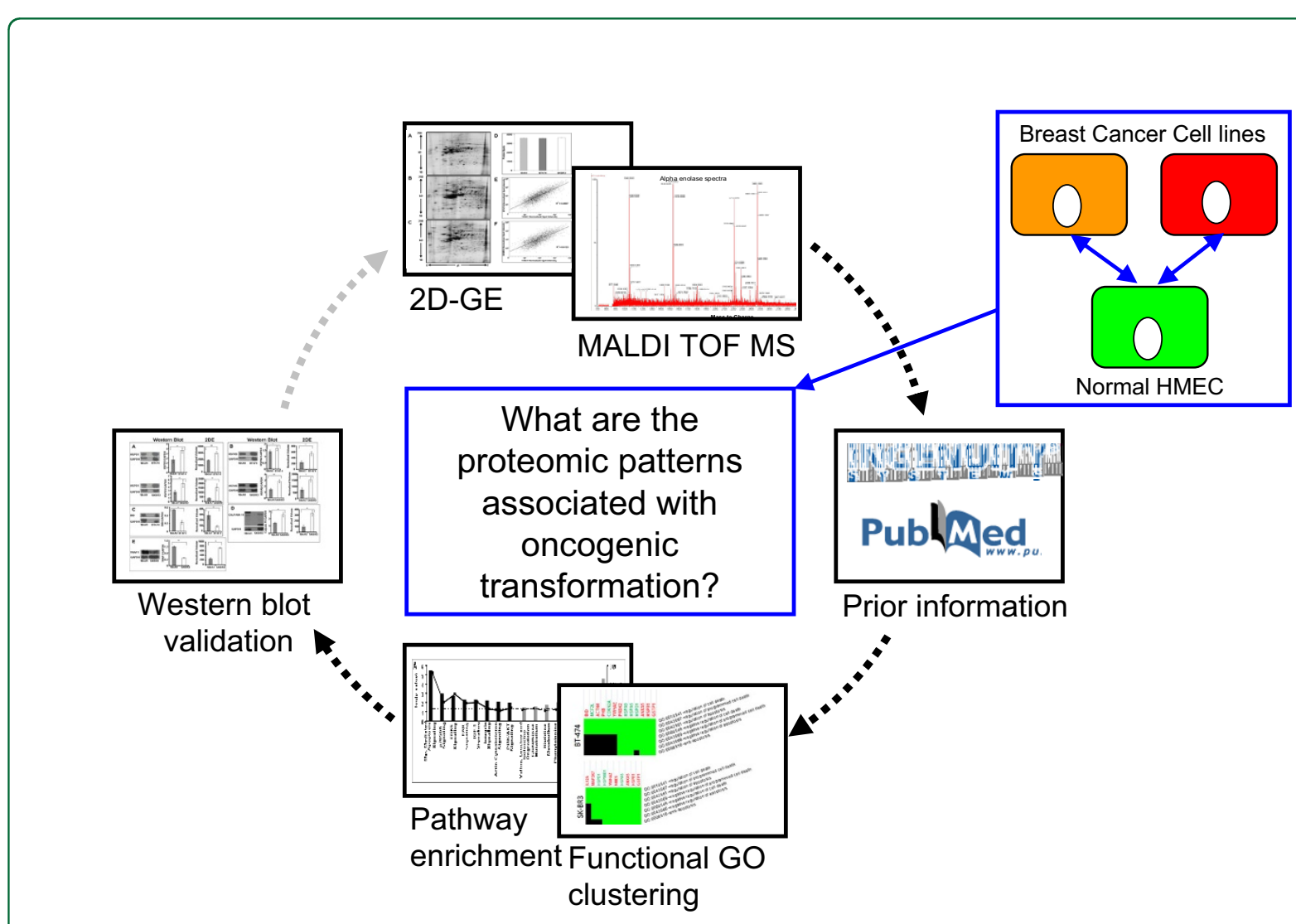

Interpreting proteomics profiles of three human mammary epithelial cell models using prior information reveals molecular alterations associated with oncogenic traits.

\title{
Protein-based identification of quantitative trait loci associated with malignant transformation in two HER2+ cellular models of breast cancer
}

Kulkarni and Klinke 


\title{
Protein-based identification of quantitative trait loci associated with malignant transformation in two HER2+ cellular models of breast cancer
}

\author{
Yogesh M Kulkarni ${ }^{1}$ and David J Klinke $\|^{1,2^{*}}$
}

\begin{abstract}
Background: A contemporary view of the cancer genome reveals extensive rearrangement compared to normal cells. Yet how these genetic alterations translate into specific proteomic changes that underpin acquiring the hallmarks of cancer remains unresolved. The objectives of this study were to quantify alterations in protein expression in two HER2+ cellular models of breast cancer and to infer differentially regulated signaling pathways in these models associated with the hallmarks of cancer.

Results: A proteomic workflow was used to identify proteins in two HER2 positive tumorigenic cell lines (BT474 and SKBR3) that were differentially expressed relative to a normal human mammary epithelial cell line (184A1). A total of 64 (BT474-184A1) and 69 (SKBR3-184A1) proteins were uniquely identified that were differentially expressed by at least 1.5 -fold. Pathway inference tools were used to interpret these proteins in terms of functionally enriched pathways in the tumor cell lines. We observed "protein ubiquitination" and "apoptosis signaling" pathways were both enriched in the two breast cancer models while "IGF signaling" and "cell motility" pathways were enriched in BT474 and "amino acid metabolism" were enriched in the SKBR3 cell line.

Conclusion: While "protein ubiquitination" and "apoptosis signaling" pathways were common to both the cell lines, the observed patterns of protein expression suggest that the evasion of apoptosis in each tumorigenic cell line occurs via different mechanisms. Evidently, apoptosis is regulated in BT474 via down regulation of Bid and in SKBR3 via up regulation of Calpain-11 as compared to 184A1.
\end{abstract}

Keywords: MALDI-TOF MS, Proteomics, Breast cancer, Malignant transformation, Two dimensional gel electrophoresis, Ingenuity pathway analysis

\section{Background}

Cancer cells exhibit a number of common traits that differentiate themselves from normal cells, including sustained proliferative signaling, resisting cell death, and evading growth suppressors [1]. Acquiring one of the hallmarks of cancer is associated with activating/deactivating particular genes, called oncogenes/tumor suppressors. The focus on identifying specific oncogenes or tumor suppressors that drive malignant transformation embodies the genomic era in cancer research [2]. However, a series of recent developments challenge this

\footnotetext{
* Correspondence: david.klinke@mail.wvu.edu

'Department of Chemical Engineering, College of Engineering and Mineral Resources, West Virginia University, Morgantown, WV 26506, USA Full list of author information is available at the end of the article
}

oncogene paradigm. Next generation sequencing efforts have revealed that, instead of a small number of genetic alteration associated with malignant transformation [3], genomic landscapes are extensively modified in solid tumors $[4,5]$. These massive rearrangements suggest that there might not be single driver mutations, but that the quantitative alterations in cellular traits associated with malignant transformation is distributed among multiple genetic loci. These quantitative trait loci (QTL) manifest themselves by altering the flow of intracellular information among signaling pathways [6]. In addition, evolutionary theory suggests that cancer cells are alternative solutions to a multivariate optimization problem where the tumor microenvironment provides the selective landscape [7]. Collectively, these findings suggest a more

\section{C) Biomed Central}


global approach towards identifying the molecular alterations associated with oncogenic transformation.

Gene microarray platforms provide tremendous breadth in surveying the gene expression landscape within a cellular system. However, relating gene expression with the specific role that the corresponding protein plays in a signaling pathway is complicated by posttranscriptional control of protein expression [8] and tight regulation of protein activity [9]. In contrast to genomic-based assays, proteomics provides an attractive platform to profile this regulatory layer of protein activity and differences in the level of protein expression [10]. Similar to QTL analysis [11], differences in proteomic patterns across biological systems that exhibit quantitative differences in traits provide an unbiased perspective to identify molecular mechanism that underpin these differences in phenotype. In contrast to QTL analysis, the direct relationship between proteomic profiles and cellular traits implies that a smaller sample size can still yield meaningful insight. High-throughput quantitative proteomic analysis has previously been used to identify differentially expressed proteins and pathways associated with breast tumor phenotypes [12]. Also networks derived from the differences in expression of key specific biochemical molecules between normal and transformed hepatocytes uncovered profound differences in the immune response between these cells [13]. More generally, knowledge of molecular mechanisms that associate with cellular traits may lead to new therapeutic strategies or new fundamental understanding of the corresponding signaling pathways. Despite this promise, the proteomic loci, as a manifestation of underlying genetic alterations that are associated with oncogenic transformation in breast cancer, remain unclear.

Breast cancer is a clinically heterogeneous disease with a variety of distinct subgroups of tumors endowed with different phenotypes and clinical outcomes. Using profiles of gene expression, breast cancers are divided into five major subtypes: triple-negative (ER-/PR-/ HER2-), luminal A (ER/PR+,HER2-), luminal B (ER/PR/ HER2+), HER2+/ER-, and normal breast-like (ER/PR/ HER2-, CK5/6,HER1+) [14-16]. Clinical presentation is distributed among the breast cancer subtypes: $68 \%$ were luminal A, 9.5\% were luminal B, 9.5\% were HER2+/ERand $13 \%$ were triple-negative and normal breast-like $[17,18]$. Particular subtypes also express unique patterns of proteins. For instance, HER2 expression is more common in HER2+/ER- and luminal B subtypes. Ki-67 and TP53 expression is rarely associated with luminal A subtype as compared to others. While these subtypes are defined to help tailor treatment options, it is unclear what pathway alterations occur in concert with ER/PR/ HER2 amplification. In this study, our objective was to identify proteins that are differentially expressed in two
HER2+ phenotypes of breast cancer (BT474 and SKBR3) as compared to a cell line that is reflective of normal mammary epithelium (184A1) using gel-based proteomics. Differences in protein expression were then analyzed using systems biology tools to identify the functionally enriched pathways. Immunoblotting was used to validate the patterns of protein expression observed using a proteomics workflow. In summary, we found that differentially expressed proteins in BT474 were overrepresented by proteins involved in cell proliferation and those in SKBR3 were overrepresented by proteins involved in amino acid metabolism. Differential protein expression also suggests that apoptosis signaling, a functionally enriched pathway that is inhibited in both the tumor phenotypes might have independent mechanisms unique to each tumor phenotype. In BT474, apoptosis is regulated by under-expression of Bid in comparison with 184A1; whereas, it occurs in SKBR3 by over-expression of Calpain-11 as compared to 184A1.

\section{Results}

\section{Identifying proteins differentially expressed in breast} tumor cell lines

\section{DE and image analysis}

Representative pattern of cellular proteome obtained in the $\mathrm{pH}$ range 4-7 after 2DE of total cellular extracts is shown in Figure 1 with more than 3,500 unique protein spots resolved in each cell line (Figure 1D). The proteomic pattern for each cell line was highly reproducible among biological replicates (Additional file 1: Figure S1) with a dynamic range spanning four orders of magnitude and a strong correlation between normalized intensities for matching spots (Figure $1 \mathrm{E}$ and $1 \mathrm{~F}$ ). Considering that there may be some basal differences in protein expression among these cell lines, a protein was considered differentially expressed if it was deregulated by a factor of at least 1.5 -fold. Comparing the relative spot intensities in the 184A1 to BT474 cell lines revealed a total of 329 spots that showed a significant $(p$ $<0.05)$ difference in expression by at least 1.5 -fold. Similar comparison in 184A1 and SKBR3 proteomic profiles revealed 265 spots to have a significant $(p<$ 0.05 ) expression change by at least 1.5 -fold. Out of these, 110 well-resolved spots were selected in cell lines $184 \mathrm{~A} 1$ and BT474 and 109 well-resolved spots were selected in cell lines 184A1 and SKBR3. An example of a well-resolved protein spot with its presence in each gel across both the cell lines is shown for 184A1-BT474 (Figure 2A) and 184A1-SKBR3 (Figure 2B) comparisons. The normalized volume of the spot in each cell line with the fold-change and significance is shown for 184A1-BT474 (Figure 2C) and 184A1-SKBR3 (Figure 2D) respectively. 


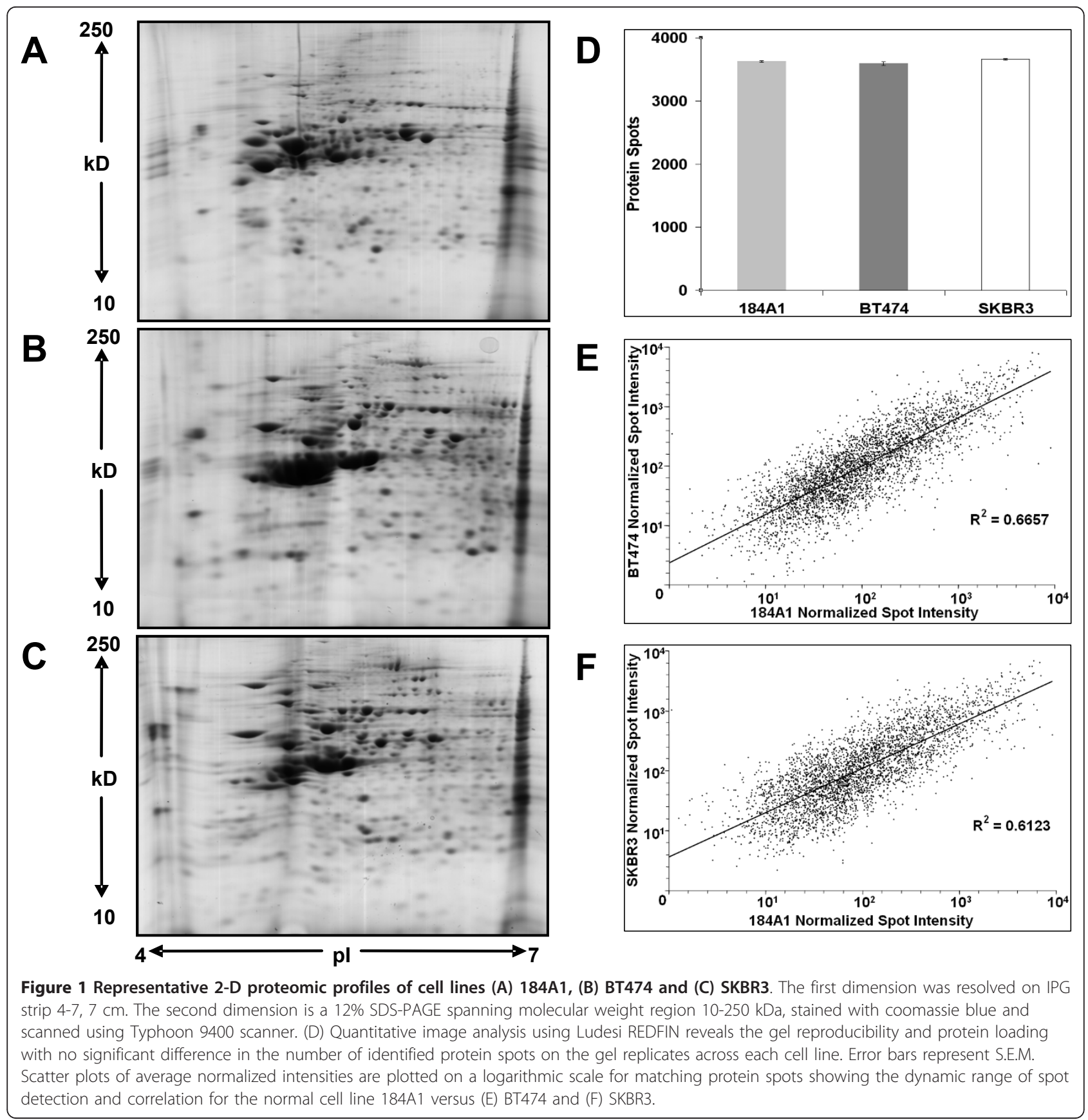

\section{Peptide mass fingerprinting}

The selected protein spots were excised, in-gel digested by trypsin and analyzed by MALDI-TOF MS to generate a peptide mass fingerprint. The resulting peptide mass fingerprints were queried against the Swiss-Prot human database using Mascot as a primary database search algorithm. Expasy Aldente was used as a complementary algorithm for additional confirmation to reduce the possibility of false positive identification (Additional file 2: Table S1 and Additional file 3: Table S2). Agreement between the apparent $\mathrm{M}_{\mathrm{r}}$ and $\mathrm{pI}$ observed on the 2-D gel and the theoretical values of the identified proteins provided additional support for positive identification. As an example, peptide mass fingerprints with the tryptic peptide mass values that contributed towards protein identification are shown for Probable ribonuclease-11 (RNASE11) in 184A1-BT474 and 3-hydroxy isoburate dehydrogenase (HIBADH) in 184A1-SKBR3 in Figure 2. From 110 picked spots, 96 differentially expressed proteins were identified in the 184A1-BT474 comparison. For the 184A1-SKBR3 comparison, 94 proteins were identified from 109 picked spots. These differentially expressed proteins that were 


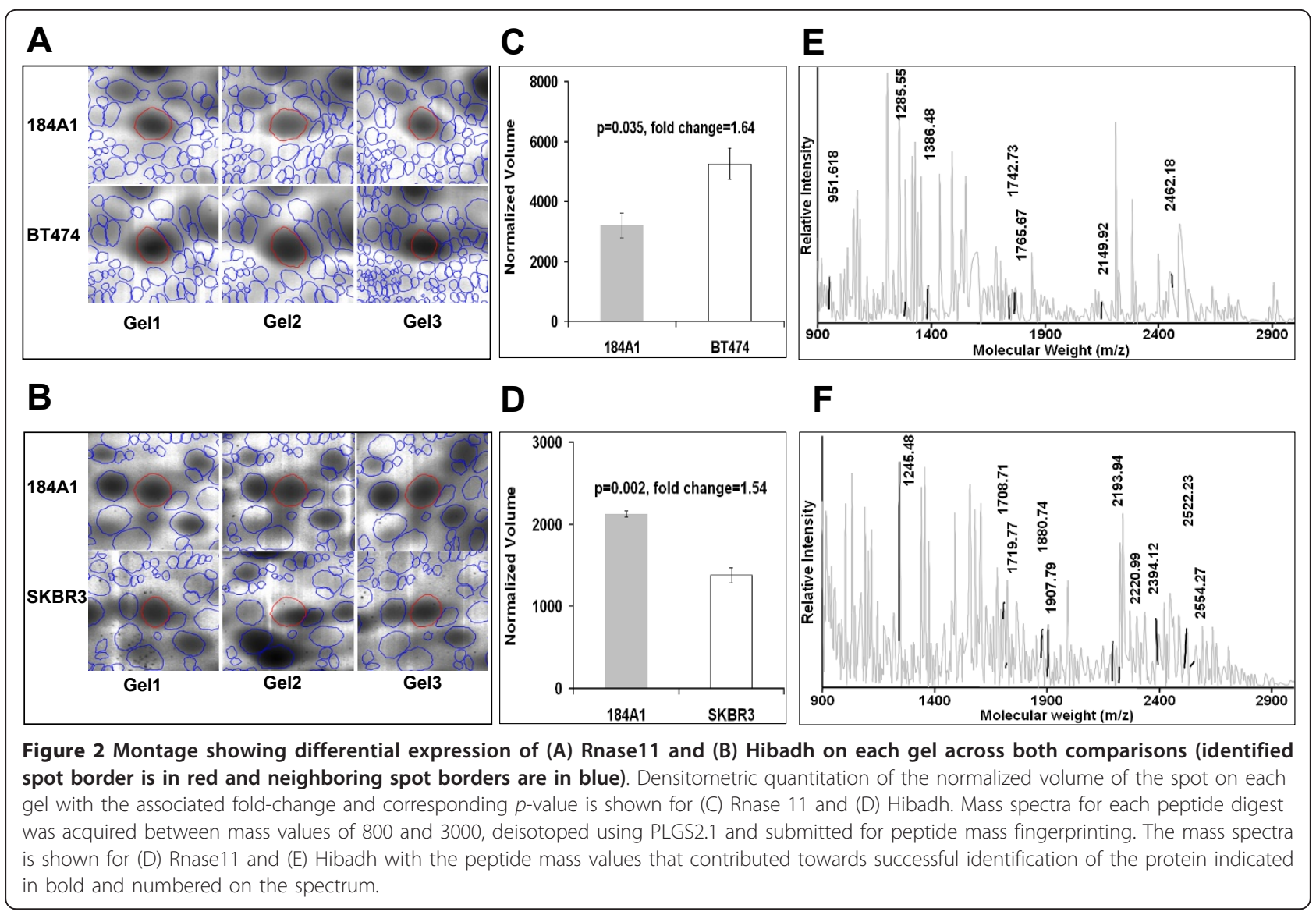

identified in BT474 (Figure 3A) and in SKBR3 (Figure 3B) are encircled red on the proteome map of 184A1. Out of these, 64 proteins were unique to the 184A1-BT474 dataset and 69 proteins were unique to the 184A1-SKBR3 dataset. Some of the identified proteins may exist in multiple forms, as they were associated with multiple protein spots. It is unclear as to whether these proteins exist in multiple forms due to biological differences or processing influences such as carbamylation, a common modification when using urea buffer, that causes shifts in the isoelectric point of the protein. Different forms of keratins, a common source of contamination in this method of identifying proteins by in-gel digestion and PMF, also formed a small subset of identified proteins and were excluded from all subsequent analysis. More than $95 \%$ of the spots had sequence coverage exceeding $25 \%$. These differentially expressed proteins (Table 1) formed the dataset for pathway analysis and network generation.

\section{Pathway analysis and protein interaction network generation using IPA}

Using the list of differentially expressed proteins for each pairwise comparison, we annotated those patterns with biological function by quantifying biological pathways that were enriched in the data sets. A statistical test, the Fisher exact test with a Benjamini-Hochberg correction, was used to assess the conditional probability of observing multiple patterns associated with a given pathway by chance alone. This statistical test was applied to all of the canonical pathways contained within the IPA library. In addition, the ratio of observed proteins relative to the total number of proteins in a pathway provided an additional metric for pathway enrichment. The results from this pathway analysis are summarized in Figure 4. Some pathways were found to be unique to each cell line (Figure 4A) and some were common to both the cell lines (Figure 4B). The most significant canonical pathway associated with differentially regulated proteins in BT474 cell line was the "Protein Ubiquitination Pathway" when ranked by significance $\left(p<5.5 \times 10^{-7}\right)$ with nine molecules (HSPA5, HSPA9, HSPA1L, HSPB1, HSPD1, PSMB1, PSMC2, PSMC4, and PSME1) out of a possible 274 associated with the pathway. "Myc Mediated Apoptosis Signaling" was the most significant pathway $(p<3.62 \times$ $\left.10^{-6}\right)$ when ranked by ratio $(0.078)$ with five focus molecules (BID, CDKN2A, RRAS2, YWHAE, YWHAQ) out of a possible 64 molecules being associated with the 


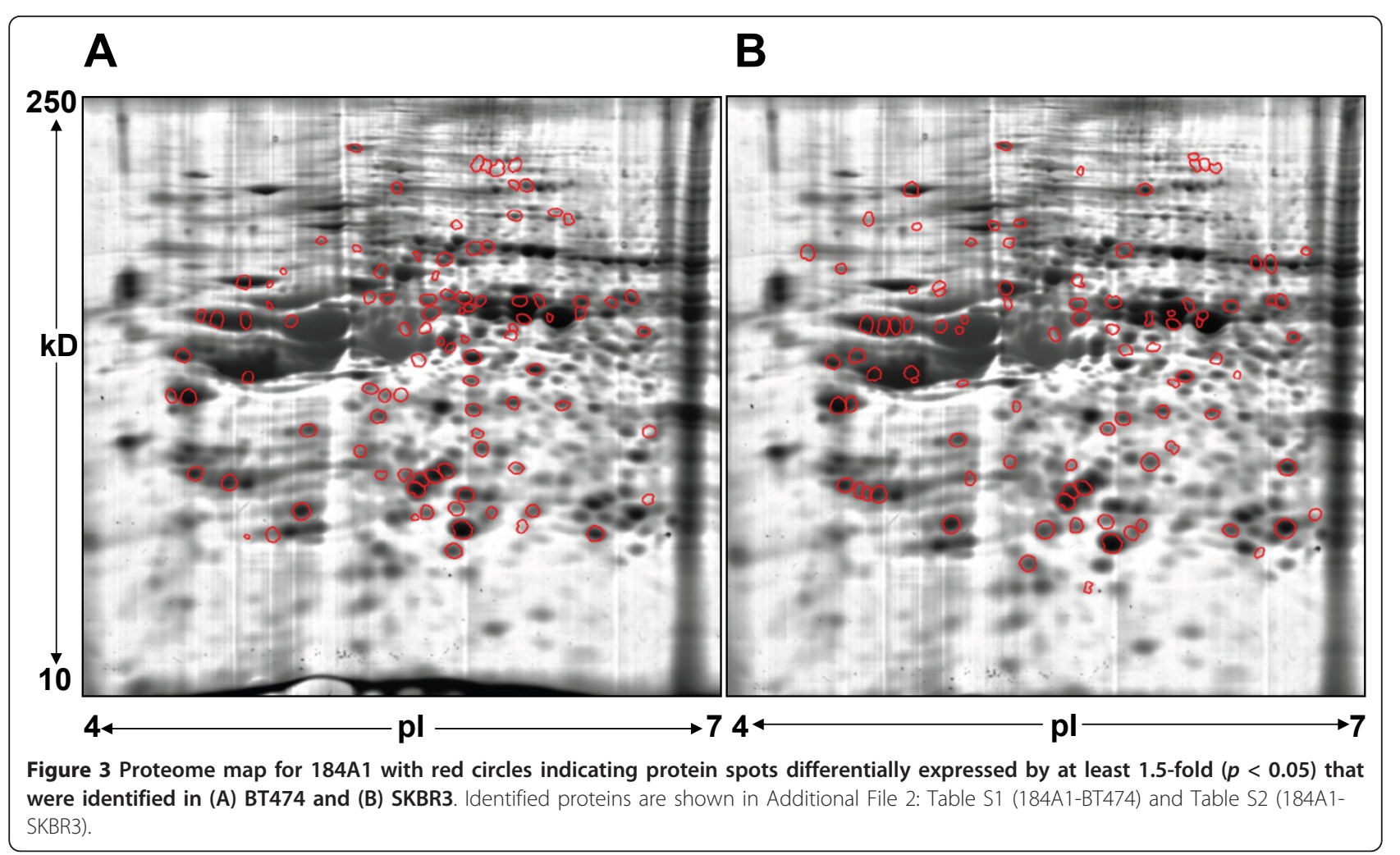

pathway. Similarly, in the SKBR3 cell line, the most significant pathway was "Purine Metabolism" when ranked by significance $\left(p<5.2 \times 10^{-7}\right)$ with ten molecules (ATP5B, HSPD1, MPP2, NME5, NME7, POLI, PRPS1, PRPSAP2, SEPT1, and TRAP1) out of a possible 439 being associated with the pathway. "EIF2 Signaling" was the most significant pathway $\left(p<2.91 \times 10^{-5}\right)$ when ranked by ratio with five focus molecules (AKT2, EIF2S1, EIF2S2, EIF3I, and PPP1CC) out of a possible 104 being associated with the pathway. Additionally, "Protein Ubiquitination Pathway" was also ranked high in SKBR3 both by significance $\left(p<1.13 \times 10^{-5}\right)$, as well as ratio with eight molecules (HSP90B1, HSPA4, HSPA5, HSPB1, HSPD1, PSMA3, PSMB8, UCHL5) out of a possible 274 associated with the pathway. In general, pathways associated with proteins differentially expressed in BT474 were found to be predominantly associated with cell motility and proliferation (ERK5, FAK, IGF-1, Integrin, and Actin cytoskeleton signaling). On the other hand, metabolic pathways (Glutathione, Histidine, Phenylalanine, Pyrimidine, and Purine Metabolism) formed a predominant group of canonical pathways associated with differentially expressed proteins in SKBR3.

Information obtained from IPA analysis relates canonical pathways to a group of genes, but lacks the ability to predict how a pathway is regulated differently. For instance, "apoptosis signaling" was a significant pathway in both the tumor cell lines, it remained unclear if this pathway was up- or down-regulated. Additional functional annotation was obtained using DAVID [19], which clusters highly related genes and their corresponding functional gene ontology annotation to generate a gene-term 2D heat map view (Figure 4C). Differentially expressed proteins from BT474 and SKBR3 were seen to be involved in negative regulation of apoptosis and programmed cell death.

To overcome the limitation of pathway-based analysis where not all human genes have been assigned to a definitive pathway; we also tried to interpret the dataset of differentially expressed proteins in terms of a proteininteraction network. The differentially expressed proteins were uploaded and mapped to corresponding "gene objects" in the Ingenuity Pathways Knowledge Base (IPKB) in which curated prior information used is a master gene interaction network. Using the BT474 data set, ten protein interaction networks were found to be statistically significant $(p<0.01)$. Six of the ten generated networks were discarded as they had only one focus molecule in the network. Similarly, six interaction networks were generated using SKBR3 data set, out of which one network was discarded on similar grounds. The remaining networks are summarized in Additional file 4: Table S3 with the list of all proteins associated with the focus genes of the network. The most significant network with the highest number of focus 
Table 1 List of unique proteins that were differentially expressed and formed the dataset for IPA analysis are listed along with the associated fold-change and $p$-value.

\begin{tabular}{|c|c|c|c|c|c|c|c|}
\hline \multicolumn{4}{|c|}{ BT-474 versus $184 \mathrm{~A} 1$} & \multicolumn{4}{|c|}{ SKBR3 versus $184 A 1$} \\
\hline Gene Symbol & Fold change $^{a}$ & Gene Symbol & Fold Change $^{a}$ & Gene Symbol & Fold change $^{a}$ & Gene Symbol & Fold change $^{a}$ \\
\hline ACTB & $1.9 \pm 0.1$ & LYN & 1.62 & AKT2 & -3.14 & LMNA & -2.6 \\
\hline ACTN4 & -3.54 & MCF2L & 2 & $\mathrm{ALDH} 2$ & -1.72 & LMNB1 & 1.98 \\
\hline ACTRT1 & -3.75 & NDE1 & 2.33 & ANXA5 & -6.5 & MAP3K7 & -4.95 \\
\hline ADSL & -2.58 & P4HB & $2.9 \pm 1.1$ & ANXA6 & 1.73 & MPP2 & 2.37 \\
\hline ALCAM & -21.5 & PCYT1B & -3.45 & APOA1 & -2.71 & MRPS35 & 5.18 \\
\hline $\mathrm{ALDH} 2$ & -2.63 & PDE4D & 2.45 & ATP5B & 3.03 & NME5 & -6.4 \\
\hline ANXA5 & $-20.5 \pm 141$ & PDE4D & -2.94 & ATP5B & $-3.2 \pm 0.6$ & NME7 & -6.4 \\
\hline ANXA8L2 & -4.24 & PHB & -2 & BPNT1 & -2.59 & $\mathrm{NQO} 2$ & -5.83 \\
\hline BCAR3 & 4.25 & PIH1D1 & -2.46 & CAPN11 & 3.52 & OPA1 & -3.06 \\
\hline $\mathrm{BID}$ & -3.19 & PMM2 & 2.74 & CMPK1 & -2.56 & $\mathrm{P} 4 \mathrm{HB}$ & 2.55 \\
\hline C10orf88 & -3.28 & POLR3E & -2.12 & CTNNA3 & -3.46 & PAF1 & -1.97 \\
\hline CAPZB & -2.05 & PPFIBP1 & 2.23 & EEF2K & 6.03 & POLI & -2.11 \\
\hline CDKN2A & 3.22 & PPM1B & 2.99 & EIF2S1 & -3.89 & PPFIBP1 & 4.18 \\
\hline CSK & -9.11 & PRDX2 & -5.03 & EIF2S2 & 4.32 & PPP1CC & 8.87 \\
\hline DPYSL4 & 1.66 & PRPSAP2 & -2.87 & EIF3I & -3.89 & PRDX6 & 3.21 \\
\hline EEFIG & -2.73 & PSMB1 & 1.76 & EVC & 10.12 & PRKAR2A & -19.47 \\
\hline EIF2B3 & -3.95 & PSMC2 & $-5.3 \pm 2.5$ & FAM102B & 2.08 & PRPS1 & -5.46 \\
\hline FSTL1 & -7.6 & PSMC4 & -7.19 & $\mathrm{GDI} 2$ & -2.31 & PRPSAP2 & -2.31 \\
\hline GNA14 & -3.1 & PSME1 & $-2.2 \pm 0.6$ & GNB1L & -6.1 & PSMA3 & -3.25 \\
\hline GSTP1 & -45.37 & PTER & -6.49 & GOLGA8F & 4.17 & PSMB8 & -3.7 \\
\hline $\mathrm{HIBADH}$ & -2.86 & RAB27B & -1.83 & GRK4 & $-2.8 \pm 0.4$ & RAB37 & -2.17 \\
\hline HORMAD1 & -1.63 & RAB37 & $-2.9 \pm 0.4$ & GSTP1 & -22.92 & RABIL1 & -3.01 \\
\hline HSPA1L & -3.53 & RAB3A & 3.45 & GTF3C4 & 3.69 & RMND1 & -3.13 \\
\hline HSPA5 & 2.21 & RGN & -1.62 & HIBADH & -1.54 & RNASE11 & -9.38 \\
\hline HSPA9 & $5.0 \pm 3.2$ & RNASE11 & 1.64 & HNRNPF & 2.63 & SEMG2 & -5.53 \\
\hline HSPB1 & -2.48 & RNPEPL1 & -1.93 & HSP90B1 & 1.57 & SEPT1 & -3.58 \\
\hline HSPD1 & $3.4 \pm 0.9$ & RRAS2 & -10.1 & HSPA4 & -2.48 & SERPINB5 & -6.06 \\
\hline IFT74 & $1.9 \pm 0.2$ & SACM1L & 3.23 & HSPA5 & 2.14 & SIKE1 & $-3.3 \pm 1.3$ \\
\hline IGBP1 & -5.6 & SERPINB5 & -3.59 & HSPB1 & -3.42 & ST3GAL4 & -2.79 \\
\hline KRT1 & -2.42 & SRSF9 & 2.37 & HSPD1 & 4.31 & TBCC & $-3.7 \pm 1.5$ \\
\hline KRT13 & -4.38 & TBCC & -12.07 & ILI2A & -2.6 & TFB1M & -4.55 \\
\hline KRT15 & $-6.2 \pm 1.4$ & TPRG1 & -2.02 & KIAA1524 & 11.9 & TRAP1 & 2.73 \\
\hline KRT17 & -2.37 & YWHAE & -3.29 & KRT15 & $-9.1 \pm 2.5$ & TUBA1B & 2.51 \\
\hline KRT18 & $4.0 \pm 1.3$ & YWHAQ & -2.97 & KRT17 & $-7.7 \pm 1.8$ & TUBA1B & -2.11 \\
\hline KRT5 & $-11.6 \pm 3.0$ & & & KRT2 & -5.14 & TUBBA2A & 3.28 \\
\hline KRT6A & -1.86 & & & KRT24 & -3.75 & UCHL5 & -2.68 \\
\hline KRT6B & $-3.5 \pm 0.3$ & & & KRT5 & -5.35 & VPS39 & -1.97 \\
\hline KRT83 & -2.5 & & & KRT6A & $-4.0 \pm 1.7$ & YWHAZ & $-4.5 \pm 0.5$ \\
\hline LRPPRC & $6.2 \pm 1.2$ & & & LCMT1 & -1.58 & & \\
\hline
\end{tabular}

Fold-change of proteins identified multiple times is indicated with the S.M.M and the highest $\mathrm{p}$-value associated with any of the spots. Proteins indicated in bold are up-regulated in 184A1 in comparison with both tumor cell lines. Proteins indicated in bold and italicized are up-regulated in both tumor cell lines in comparison with 184A1

${ }^{a}$ A positive fold change indicates greater expression in the cancer cells line while a negative fold change indicates a greater expression in $184 \mathrm{~A} 1$ 


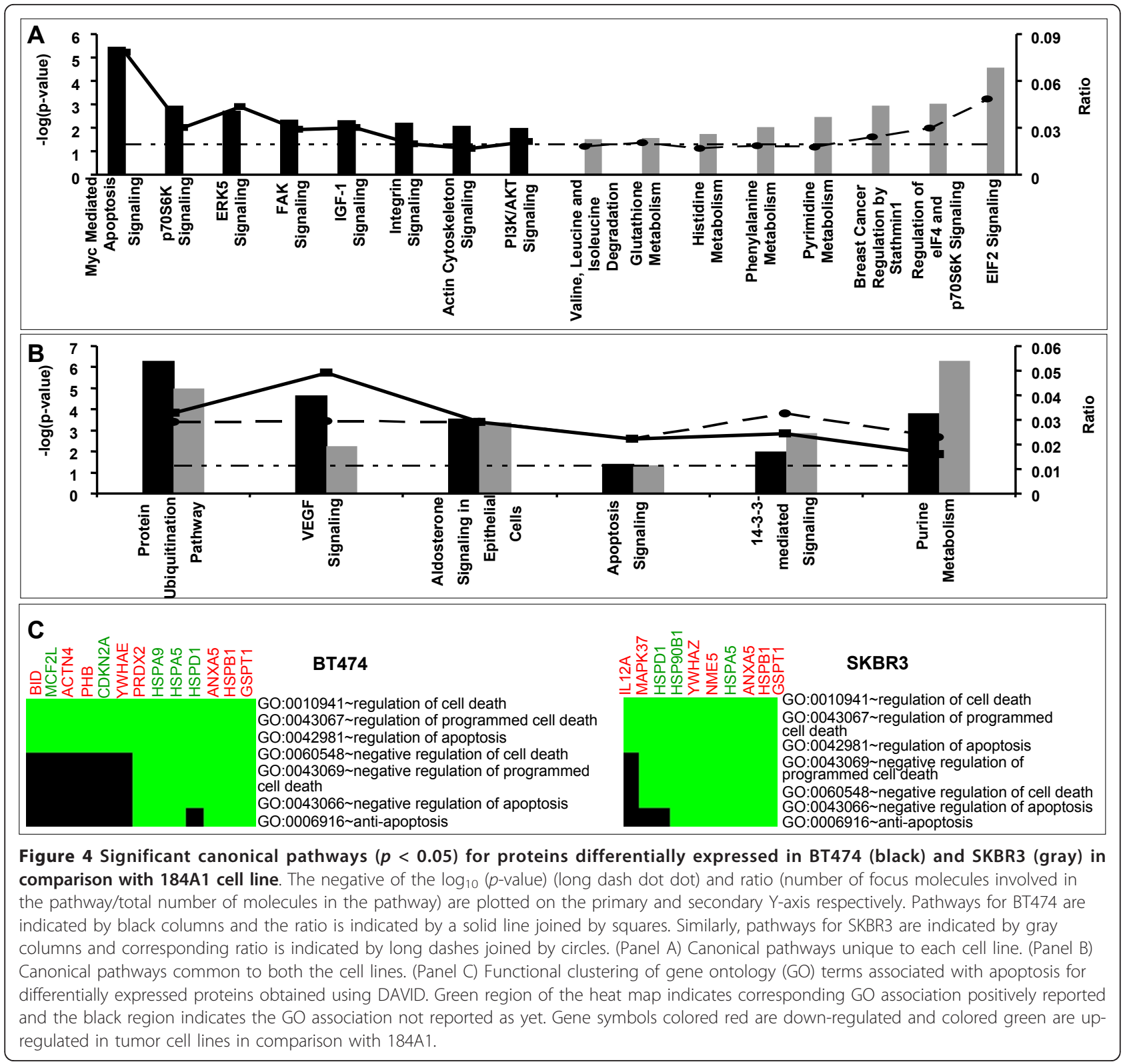

molecules in BT474 had a $p$-value $<10^{-48}$ with 23 focus genes mapped onto a network of 35 molecules as shown in Figure 5 $\mathrm{A}$ and had functions associated with "Cell Death" and "Protein Synthesis". The most significant network in SKBR3 $\left(p<10^{-57}\right)$ had 24 focus molecules mapped onto the protein interaction network consisting of 35 molecules (Figure 5B) and had functions associated with "Cell Morphology" and "Protein Degradation". NF- $\kappa$ B complex formed a major hub at the centre of the network in BT474 as well as SKBR3, with a number of direct and indirect interactions with the focus molecules in the network. The intensity of the node color represents the degree of up- (red) or down-(green) regulation in tumor cell lines. Validation of these nodes is an important step as they are major gene regulators and deletion of any of these nodes may influence the inferred network.

\section{Validation of proteomics results using immunoblotting}

We confirmed the differential expression of proteins inferred from the proteomics results using immunoblotting. Some of the proteins that were involved in the most significant pathways of both the cell lines were selected for validation. These proteins were HSPA5 and HSPD1, which are both involved in "Protein Ubiquitination Pathway", for BT474, and HSPD1 and TRAP1, which are both part of "Purine Metabolism" pathway, for SKBR3 cell line. "Apoptosis Signaling", a hallmark of 


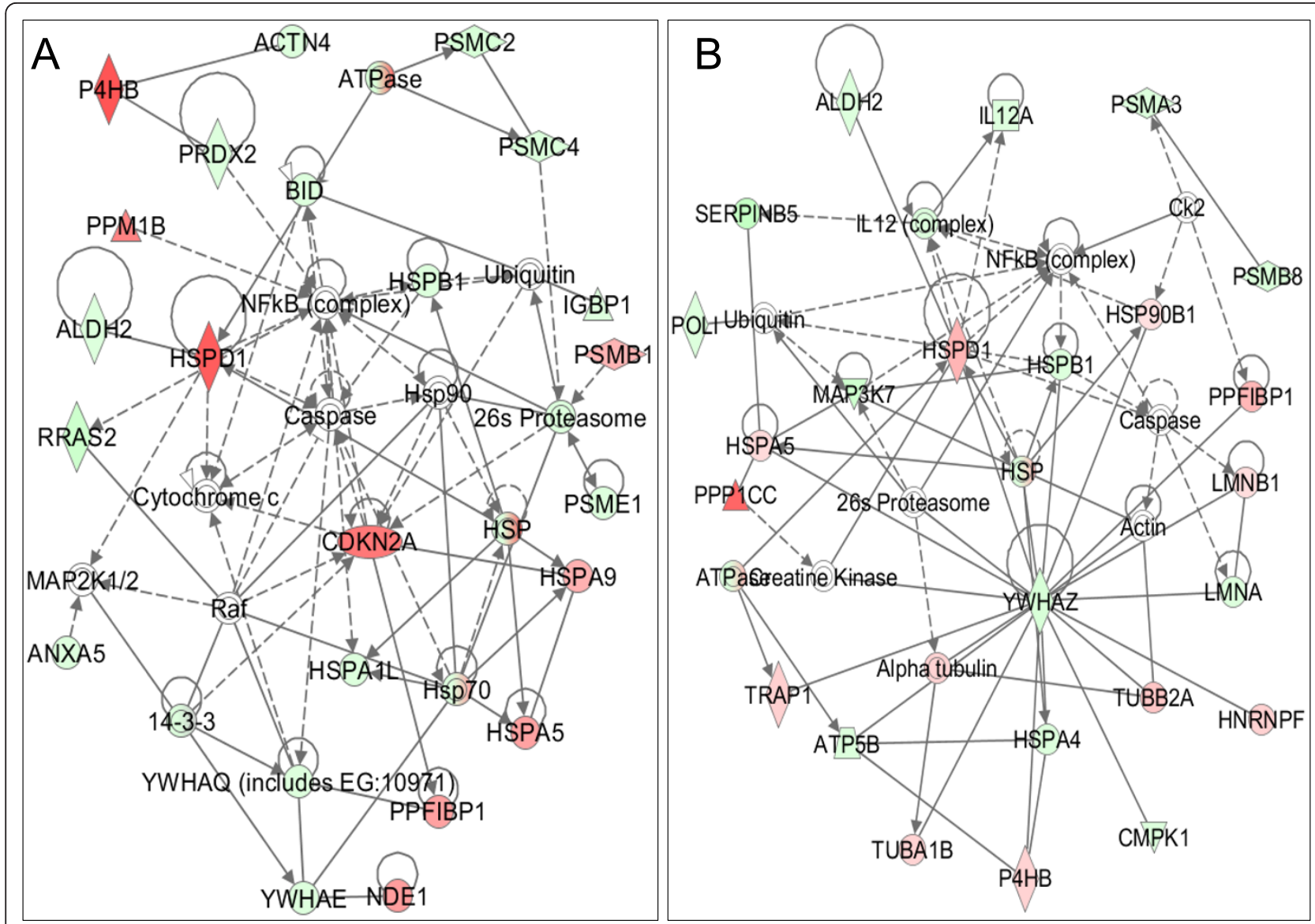

Figure 5 Proteins differentially expressed in (A) BT474 and (B) SKBR3 in comparison with 184A1 were overlaid onto a global molecular network developed from information contained in the Ingenuity Knowledge Base (IKB). Genes or gene products are represented as nodes, and the biological relationship between two nodes is represented as an edge (line). Solid lines indicate a direct relationship and dashed lines indicate an indirect relationship between nodes. The intensity of the node color represents the degree of up- (red) or down- (green) regulation. White nodes represent the IKB molecules associated with focus genes. Network reflects (A) Cellular Function and Maintenance, Cell Death, and Protein Synthesis $\left(p<10^{-48}\right)$ and (B) Cell Morphology, Cellular Function and Maintenance, and Protein Degradation $\left(p<10^{-57}\right)$.

cancer and a significant pathway in BT474 $(p<0.04)$ and SKBR3 $(p<0.05)$ was also selected for validation. Interestingly, different proteins were involved in apoptosis signaling in both the cell lines. In BT474, BH3 domain interacting death agonist (Bid) and RRAS2 were involved in apoptosis signaling. On the other hand, Calpain-11 (CAPN11) and LMNA were a part of apoptosis signaling pathway in SKBR3. Of these, BID and CAPN11 were selected to validate the differential expression.

As summarized in Figure 6, western blotting analysis provided consistent results as compared to the gelbased proteomics results. HSPD1 (Figure 6A) was detected in three locations in the 184A1-BT474 proteomic analysis, possibly due to processing influences, and was upregulated in BT474 by $3.88\left(p<4.2 \times 10^{-}\right.$ $4), 1.6(p<0.04)$, and $4.6(p<0.02)$-fold respectively.
In SKBR3, HSPD1 was upregulated by a factor of 4.3 $(p<0.03)$. HSPA5 (Figure 6B) was upregulated in BT 474 by 2.2 -fold $(p<0.02)$ as well as in SKBR3 by 2.1 -fold $(p<0.03)$. BID (Figure $6 \mathrm{C}$ ) was found to be downregulated in BT474 by 3.1 -fold $(p<0.05)$ and proteomic analysis found the $80 \mathrm{kD}$ isoform of CAPN11 (Figure 6D) was upregulated in SKBR3 by 3.5 -fold $(p<0.01)$ in comparison with 184A1. However, the up regulation of HSP90 (Figure 6E) in SKBR3 inferred from proteomic analysis was inconsistent with immunoblotting, which revealed the protein to be upregulated in 184A1. This inconsistent observation might be a cause of antibody specificity or the semi-quantitative nature of immunoblotting given the differences in dynamic ranges of photographic quantification of chemiluminiscence and coomassie based detection methods. 


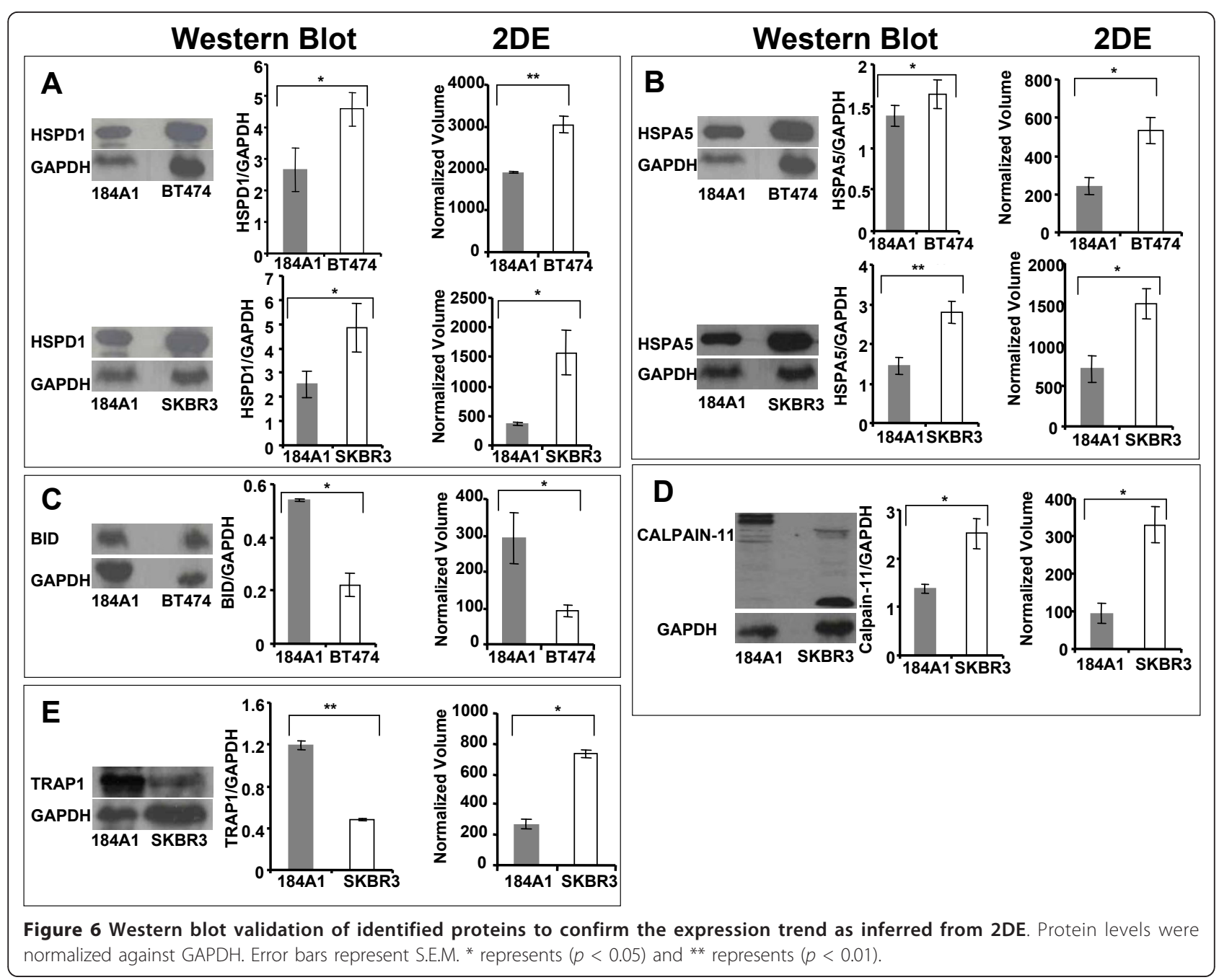

\section{Discussion}

The HER2+ cancer cell lines were selected to represent different features of breast cancer phenotypes including variations in receptor status. One of the cell lines, BT474, is derived from ER+/PR + solid invasive ductal carcinoma in the breast with a high in vitro invasion capability [20]. SKBR3, on the other hand is derived from pleural effusion adenocarcinoma, is negative for both, ER and PR, and exhibits a low in vitro invasion capability [21]. The non-tumorigenic cell line selected as a reference for comparison of differential protein expression was $184 \mathrm{~A} 1$ as it has a lower proliferation rate as compared to other non-tumorigenic epithelial cell line, such as MCF10A [22]. The 184A1 cell line was established from a normal mammary tissue, transforming it by exposure to benzo(a)pyrene, thereby making it immortal but not malignant. In the Biology of Cancer, Robert Weinberg states that normal and cancer cells "utilize control circuitry that is almost identical. Cancer cells discover ways of making relatively minor modifications of the control machinery operating inside cells. They tweak existing controls ..." (emphasis added pg 159) [23]. Identifying these subtle differences in signaling circuitry will help understand the mechanistic basis for cancer. By focusing on a small subset of cancer cell lines, we aimed to identify these subtle differences that are lost when averaged across many different cell lines. Here we assume that the observed proteomes reflect intrinsic differences in the genetic regulatory structure that is altered in cancer. Thinking of cancer as an evolutionary process, the BT474 and SKBR3 cell lines reflect two genetic solutions to a survival problem physically encoded as the tumor microenvironment. We used proteomics to explore the characteristics of these genetic solutions. By setting a higher threshold for inclusion in the study (i.e., greater than 1.5-fold difference), we tried to focus our functional annotation on proteins that may play a role in malignant transformation. In the following paragraphs, we will highlight some of the intriguing aspects associated with differential 
regulation of IGF, protein ubiquitination, and apoptosis signaling pathways within these three cell models.

The pathway enrichment results suggest that flux through the IGF signaling pathway is enhanced in the BT474 relative to 184A1. Previously, we found that IGF signaling and IGF1R expression were enhanced in the BT474 relative to SKBR3 [24]. IGF signaling has been implicated in regulating epithelial-to-mesenchymal transition [25], a phenomenon associated with increased cell motility and poor treatment outcome [26,27]. The IGF signaling pathway shares common effector pathways with the insulin signaling pathway [28]. Here, the 184A1 cell line should have a higher level of insulin signaling based upon the concentration of insulin used in the tissue culture media. This is interesting as model-based inference suggests that the BT474 cell line, in contrast to both the SKBR3 and 184A1 cell lines, exhibits noncanonical activation of the IGF pathway following activation of the EGF receptor [29]. Over-expression of HER2 increases the potential for autocrine activation of the EGF receptor [30]. Validating the mechanistic explanation for these observed differences in insulin/insulin growth factor signaling is on-going.

Protein ubiquitination pathway was a highly significant pathway associated with both BT474 and SKBR3 cell lines and involved mainly proteasome subunits and heat shock proteins. As shown in Table 1, most of the proteasome subunits were downregulated (PSMA3, PSMB8, PSMC2, PSMC4, UCHL5) and heat shock proteins were upregulated (HSP90B1, HSPA5, HSPB1, HSPA9) as compared to 184A1. Down-regulation of proteasome subunits might indicate weakening of the ubiquitin-proteasome system thereby accumulating abnormal proteins that in turn might confer growth and malignant potential in these tumor cells. This might be leading to an increased turnover of heat shock proteins, which function as chaperones, to prevent the accumulation of aggregated proteins resulting from proteasome inhibition $[31,32]$. Heat shock proteins (HSP's) are a family of stress response proteins that play an important role in protein folding and translocation. Elevated levels of HSP's have been reported in breast cancer cells [33,34]. Overexpression of HSPA5 has been demonstrated in ER + as well as ER- tissues compared to normal tissues ranging from 1.8- to 20-fold [35]. In this study, HSPA5 was overexpressed by a factor of 2.2 -fold $(p<0.02)$ in BT474 $(\mathrm{ER}+)$ and 2.1-fold $(p<0.03)$ in SKBR3 (ER-). Barazi et al. [36] have shown that HSPD1 can directly activate the function of $\alpha_{3} \beta_{1}$ integrin, which plays an important role in tumorigenesis and metastasis of breast cancer. Additionally, Li et al. [37] have demonstrated the presence of HSPD1 at higher levels in MDA-MB435HM (highly metastatic) cells compared to the parental cell line. They conclude that HSPD1 could be one of the potential biomarkers for breast cancer progression and metastasis.

Apoptosis signaling, another pathway common to both BT474 and SKBR3 inferred from the differential protein expression, is a process whereby cells commit to a program of organized cell death in response to external cues, such as TRAIL, or internal triggers such as DNA damage or aberrant cell cycling [38-40]. Initiation of apoptosis is regulated by the balance between pro-apoptotic proteins; such as Bax, Bak, Bad or Bid; and proteins that inhibit apoptosis, such as Bcl-2 or Bcl-XL. The balance among these proteins that promote or inhibit apoptosis determines ultimate cell fate. Quantifying gene expression is one alternative approach; however many of these apoptosis related proteins are post-translationally regulated in cancer cell lines. Bid (BH3-interacting domain death agonist) is an apoptosis inducing protein [41], which upon activation engages the pro-survival Bcl-2-like proteins via the $\mathrm{BH} 3$ domain and inactivates their function [42]. Given the BH3-only proteins' ability to induce apoptosis, there has been an increasing interest in the field of cancer therapeutics to create 'BH3 mimetics' as novel anti-cancer agents $[43,44]$. Downregulating expression of Bid has been shown to make cells resistant to Fas-mediated apoptosis [45]. BT474 cells have also been shown to be resistant to TRA-8, an agonistic antibody to death receptor 5 that induces apoptosis in various cancer cells [46]. Preclinical studies in mouse xenografts have shown that in the presence of ispinesib, a chemotherapeutic, expression of proapoptotic proteins Bax and Bid was lower in BT474 as compared to MDA-MB-468, whereas antiapoptotic protein Bcl-XL was higher [47]. Bid, which is downregulated in BT474 cell line and involved in the apoptosis signaling pathway, might suggest that this tumor cell line acquires the hallmark of evasion of apoptosis by downregulating Bid expression.

Calpain (calcium-activated neutral protease) is another protein that plays a role in apoptosis and was differentially expressed in the SKBR3 cell line relative to 184A1. Calpain exists in two isoforms: $\mathrm{m}$ - and $\mu$-calpain as 80 $\mathrm{kDa}$ and $30 \mathrm{kDa}$ isoforms, where the prefix refers to the concentration of calcium required for activation [48]. We observed higher levels of $80 \mathrm{kDa}$ isoform in the nontumorigenic $184 \mathrm{~A} 1$ cell line and the $30 \mathrm{kDa}$ isoform in the SKBR3 tumor cell line. The large and small isoforms have distinct expression patterns in human breast cancer. The larger subunit was observed at low expression levels in high grade tumors whereas the smaller subunit was observed at a high level in tumors derived from breast cancer patients with a poor prognosis and high risk for metastasis [49]. Though the exact function of calpain still remains unclear, evidence suggests a role in apoptosis because of its ability to cleave p53 [50] and 
mediate $\mathrm{I} \kappa \mathrm{B} \alpha$ proteolysis [51]. Calpain is known to regulate survival mechanisms in drug resistant cancer cells. Inhibiting the catalytic activity of calpain helps overcome resistance to TRAIL in colon cancer [52] and cisplatin in melanoma [53]. Kulkarni et al. [54] have demonstrated that calpain confers resistance to trastuzumab and apoptosis in HER2-positive breast cancer cells (SKBR3), deregulating calpain in turn deregulates activation of HER2 and PTEN/AKT1, and inversely inhibiting calpain helps in overcoming resistance to trastuzumab. It has been shown that calpains degrade Bid thereby dampening apoptotic signaling; and inversely calpain inhibition partially restores Bid levels and in turn cells sensitivity to apoptotic signaling [55]. Calpain overexpression in the SKBR3 cell line might indicate that this particular phenotype of breast cancer acquires the hallmark of apoptosis evasion via calpain mediated Bid degradation. This inference of inhibition of apoptosis is further supported by NF- $\kappa \mathrm{B}$, which forms a central inferred node in the IPA network for both cell lines. Implication of NF- $\kappa \mathrm{B}$ in inhibition of apoptosis and as a therapeutic target in cancer is well known [56-59]. NF$\kappa \mathrm{B}$ was also an inferred hub of a network in another global proteomic analysis of three breast cancer cell lines (MCF7, SKBR3, MDA-MB-23) in comparison with non-transformed mammary cells (MCF10A) [60].

\section{Conclusion}

In summary, we have inferred that multiple pathways are altered upon malignant transformation by comparing protein expression patterns of two HER2 positive breast cancer models with a transformed normal mammary cell line. These differences in functional traits reflect the genetic loci that are altered upon malignant transformation. Our data also suggest that a hallmark of cancer, evasion of apoptosis, even though common to both the HER2+ tumor models, might have different mechanisms of action. These data also motivate followon hypothesis-driven studies to understand how Bid and Calpain collectively regulate apoptosis, how malignant transformation alters the sensitivity of the insulin related signaling pathway to extracellular signals, and how additional signaling pathways modulate HER2 dependence. Such studies might open new perspectives for improving the efficacy of personalized medicine.

\section{Experimental procedures \\ Cell culture and reagents}

The human breast cancer cell lines (BT474 and SKBR3) were kindly provided by Dr. Jia Luo (University of Kentucky; Lexington, KY). The nontumorigenic human breast epithelial cell line 184A1 was obtained from ATCC (Manassas, VA). Cells were grown in $75-\mathrm{cm}^{2}$ plastic tissue culture flasks (Costar Corning; Corning,
$\mathrm{NY}$ ) in a humidified incubator at $37^{\circ} \mathrm{C}$ and $5 \%(\mathrm{v} / \mathrm{v})$ $\mathrm{CO}_{2}$. The BT474 cells were routinely maintained in Rosewell Park Memorial Institute (RPMI) 1640 medium (Mediatech, Inc., Herndon, VA) supplemented with 10\% (v/v) heat inactivated fetal bovine serum (FBS) (Hyclone, Inc., Logan, UT), 0.3\% (w/v) L-glutamine, $1 \%(\mathrm{v} / \mathrm{v})$ penicillin/streptomycin (BioWhittaker, Walkersville, MD) and $10 \mathrm{ng} / \mathrm{mL}$ insulin (Sigma, St Louis, MO). SKBR3 cells were maintained in Improved Modified Eagle Medium (IMEM) $\mathrm{Zn}^{2+}$ option (Invitrogen) containing $4 \mathrm{mM}$ L-glutamine, $2 \mathrm{ml} / \mathrm{L}$ L-proline, $50 \mu \mathrm{g} / \mathrm{mL}$ gentamicin sulfate supplemented with 10\% FBS (Hyclone) and 1\% penicillin/streptomycin (BioWhittaker). 184A1 cell line was maintained in DMEM/Ham's F-12 (1:1) medium supplemented with $5 \%(\mathrm{v} / \mathrm{v})$ horse serum (Invitrogen) in the presence of $20 \mathrm{ng} / \mathrm{mL}$ rhEGF, $10 \mu \mathrm{g} / \mathrm{mL}$ insulin and $0.5 \mu \mathrm{g} / \mathrm{mL}$ hydrocortisone (Sigma, St Louis, MO). Media was changed every 3 days and cells were passaged in a 1:3 dilution at approximately $80 \%$ confluence.

\section{Sample preparation for 2-DE}

Sample preparation for 2DE was done as we have previously described [24]. Briefly, cells were incubated in lysis buffer (7 M Urea, $2 \mathrm{M}$ thiourea, 2\% (w/v) CHAPS) for $30 \mathrm{~min}$ on ice and sonicated for five cycles in an ultrasonic water bath, where each sonication was performed for $30 \mathrm{~s}$ followed by $30 \mathrm{~s}$ cooling interval on ice. Cell debris were pelleted by centrifugation at 14,000 $\mathrm{rpm}$ for $40 \mathrm{~min}$ at $4^{\circ} \mathrm{C}$. The supernatant was aliquoted in fresh tubes and stored at $-80^{\circ} \mathrm{C}$. The protein concentration was determined using $\mathrm{CB}-\mathrm{X}^{\mathrm{TM}}$ protein assay $(\mathrm{G}$ Biosciences).

\section{2-D electrophoresis}

For each cell line, $120 \mu \mathrm{g}$ of cell lysate was mixed with rehydration buffer (7 $\mathrm{M}$ urea, $2 \mathrm{M}$ thiourea, 2\% CHAPS, 1\% DTT, 2\% IPG buffer, 0.002\% bromophenol blue) and incubated for $1 \mathrm{~h}$ at room temperature prior to rehydration on Immobilized pH Gradient (IPG) strips pH 4-7, 7 $\mathrm{cm}$, (GE Healthcare, Uppsala, Sweden) for $12 \mathrm{~h}$ at $25^{\circ} \mathrm{C}$. Isoelectric focusing was done using Ettan IPGphor apparatus (Amersham Biosciences) for a total of $17 \mathrm{kVh}$ at $50 \mu \mathrm{A}$ per strip at $20^{\circ} \mathrm{C}$ in the following steps: step-nhold at $300 \mathrm{~V}$ for $4 \mathrm{~h}, 1000 \mathrm{~V}$ gradient in $30 \mathrm{~min}, 5000$ $\mathrm{V}$ gradient in $1 \mathrm{~h} 30 \mathrm{~min}$, followed by step-n-hold at $5000 \mathrm{~V}$ till $17 \mathrm{kVh}$ was reached. Thereafter, IPG strips were equilibrated in $75 \mathrm{mM}$ Tris- $\mathrm{HCl} \mathrm{pH} \mathrm{8.8,} 6 \mathrm{M}$ urea, $30 \%(\mathrm{v} / \mathrm{v})$ glycerol, $2 \%(\mathrm{w} / \mathrm{v})$ SDS, $0.002 \%(\mathrm{w} / \mathrm{v})$ bromophenol blue and 1\%(w/v) DTT for $30 \mathrm{~min}$. A second equilibration step was done for another $30 \mathrm{~min}$ by replacing the DTT with $2.5 \%$ iodoacetamide. Equilibrated strips were transferred onto $12 \%$ SDS-polyacrylamide gel. IPG strips were sealed with $0.5 \%(\mathrm{w} / \mathrm{v})$ low melting point agarose in SDS running buffer containing bromophenol blue. Gels were run at $5 \mathrm{~mA}$ for $1 \mathrm{~h}$ to facilitate a gradual protein transfer from the strip onto the gel, 
and then at $10 \mathrm{~mA}$ until the dye front had run off the bottom of the gels. The coomassie stained gels were scanned using Typhoon 9400 scanner (Amersham Biosciences) at $100 \mu \mathrm{m}$ resolution at normal sensitivity. Data were saved in .gel format using ImageQuant software (Amersham Biosciences).

\section{Image analysis}

The images were analyzed using REDFIN Solo software from Ludesi. Gel images were cropped to remove the boundary region without proteins. The warping was done by choosing a reference image and spot matching was facilitated by placing approximately 10 manual vectors in each quadrant of the gel to align cognate spots at corresponding locations across different gels. Normalized spot volumes were generated from the optical densities for each individual spot to the ratio of the total spot volume in each gel. Protein spots were considered to be differentially expressed if the difference between the averages of spot densities from the nontumorigenic cell line and the tumor cell lines was 1.5 -fold or greater with $p<0.05$. More than $95 \%$ of the protein spots in the analysis were present in all six gels, with few spots being present in five out of the six gels in the analysis.

\section{In-gel digestion}

The manually excised gel spots of interest were destained in $50-50 \%$ acetonitrile/ $50 \mathrm{mM} \mathrm{NH}_{4} \mathrm{HCO}_{3}$ solution, reduced in DTT $\left(100 \mathrm{mM}, 57^{\circ} \mathrm{C}, 45 \mathrm{~min}\right)$ and alkylated with iodoacetamide (500 $\mathrm{mM}$, room temperature, $45 \mathrm{~min}$ ) in a dark room. The gel pieces were dehydrated in acetonitrile for $10 \mathrm{~min}$, were vacuum dried and rehydrated with $10 \mu \mathrm{L}$ of digestion buffer $(10 \mathrm{ng} / \mu \mathrm{L}$ of trypsin (Promega; Madison, WI) in $50 \mathrm{mM}$ $\mathrm{NH}_{4} \mathrm{HCO}_{3}$ ) and covered with $10 \mu \mathrm{L}$ of $\mathrm{NH}_{4} \mathrm{HCO}_{3}$. The samples were incubated for $16 \mathrm{~h}$ at $37^{\circ} \mathrm{C}$ to allow for complete digestion. $5 \%$ formic acid was added to stop the enzymatic digestion and the peptides were extracted in sequential steps by sonication using acetonitrile and $50 \%$ acetonitrile $/ 0.1 \%$ TFA.

\section{MALDI-TOF MS analysis}

MALDI-TOF-MS system model Micromass MALDI-R $\left(\right.$ Waters ${ }^{\circledR}$ ) was used to obtain the peptide mass fragment spectra as recommended by the manufacturer. Protein digest solutions were mixed at a 1:1 ratio with the MALDI matrix $\alpha$-cyano-4-hydroxycinnamic acid (CHCA) (Sigma-Aldrich Fluka; St. Louis, MO). $2 \mu \mathrm{L}$ of tryptic digest was applied to the MALDI plate and allowed to dry. The MALDI-TOF MS was operated in the positive ion delayed extraction reflector mode for highest resolution and mass accuracy. Peptides were ionized/desorbed with a 337-nm laser and spectra were acquired at $15 \mathrm{kV}$ accelerating potential with optimized parameters. The external calibration performed using ProteoMass Peptide MALDI-MS Calibration Kit (Sigma) provided mass accuracy of 25-50 ppm. Internal calibration was performed with the monoisotopic peaks of Angiotensin II ( $m / z: 1046.5423), \mathrm{P}_{14} \mathrm{R}$ (synthetic peptide) $(\mathrm{m} / z: 1533.8582)$ and adrenocorticotropic hormone (ACTH) (18-39) peptide ( $m / z: 2465.1989)$. Mass spectral analysis for each sample was based on the average of 1000-1200 laser shots. Peptide masses were measured from $m / z: 800$ to 3,000. The raw spectra was background subtracted, smoothed and deisotoped using ProteinLynxGlobalServer (PLGS) v2.1. The peak lists containing the $m / z$ ratio and corresponding intensity values were exported to Microsoft Excel for further processing.

\section{Protein identification using peptide mass fingerprinting} (PMF)

Peptide mass fingerprint's (PMF) obtained from MALDI-TOF MS were used to query public protein primary sequence databases for protein identification. Monoisotopic peaks resulting from internal calibrants were removed before submitting the peak lists to the databases. Mascot database search engine v2.3.02 (http://www.matrixscience.com, Matrix Science Ltd., UK) and Expasy Aldente (version 19/03/2010) were used to query the UniProtKB/Swiss-Prot human database (Release 2010_12, 523151 sequences, 184678199 amino acids) with the following settings: peptide mass tolerance of $50 \mathrm{ppm}$, one missed cleavage site, one fixed modification of carboxymethyl cysteine, one variable modification of methionine oxidation, minimum of four peptide matches and no restrictions on protein molecular mass or isoelectric point. The combined use of two different algorithms offers an advantage of cross validating and consolidating the identification through complementary use of different packages. Aldente, for example, has an added advantage of identifying protein isoforms, a feature that is absent in Mascot. A protein was considered to be positively identified only when it was a hit using both algorithms.

\section{Ingenuity pathway analysis}

Differentially regulated proteins identified by $2 \mathrm{DE}$ and PMF were further analyzed using Ingenuity Pathway Analysis (IPA; Ingenuity Systems, Mountain View, CA; http://www.ingenuity.com). IPA was used to interpret the differentially expressed proteins in terms of an interaction network and predominant canonical pathways as described in detail earlier [24]. Briefly, a dataset containing the differentially regulated proteins, called the focus proteins, for a particular cell line was uploaded into the IPA. These focus proteins were overlaid onto a global molecular network developed from the information in the IKB. Networks of these focus proteins were then algorithmically generated by including as many focus proteins as possible and other non-focus proteins from the IKB that are needed to generate the network based on connectivity. Enriched canonical pathways were 
identified from the IPA library using a Fisher's exact test adjusted for multiple hypothesis testing using the Benjamini-Hochberg correction [61]. We supplemented the results of our pathway analysis using DAVID Bioinformatics Resource 6.7 [62,63], a functional annotation tool that links expression data to their gene ontology (GO) annotation and identifies clusters of common GO terms.

\section{Western blotting}

For western blot analysis, 10-20 $\mu \mathrm{g}$ of total cell lysate was separated by SDS-PAGE using a $12 \%$ Tris polyacrylamide gel with a $4 \%$ stacking gel at $75 \mathrm{~V}$ for $4 \mathrm{~h}$. Proteins were transferred onto Bio Trace PVDF membrane (PALL Life Sciences; Pensacola, FL) at $42 \mathrm{~V}$ for $1.5 \mathrm{~h}$. Blots were washed in Tris Buffered Saline (TBS) for 5 min at room temperature, blocked for $1 \mathrm{~h}$ in TBS + $0.1 \%$ Tween 20 (TBS/T) plus 5\% dry milk at room temperature and then washed three times in TBS/T. Blots were incubated overnight at $4^{\circ} \mathrm{C}$ with primary antibodies specific for HSPA5 (MAB4846), HSP90 (AF3286), BID (AF846), HSP60 (AF1800) (all from R\&D Systems Inc., Minneapolis, MN), and Calpain11 (ab28227) (Abcam Inc., Cambridge, MA). The next day, blots were washed three times in TBS/T, incubated for $1 \mathrm{~h}$ at room temperature with anti-biotin (Cell Signaling Technology, Inc., Danvers, MA, 7727) and either an anti-mouse IgGHRP (HAF007), anti-rabbit IgG-HRP (HAF008), or antigoat IgG-HRP (HAF017) (all from R\&D Systems Inc.). Finally, the blots were washed three times in TBS/T, developed using LumiGLO reagent (Cell Signaling Technology, Inc., Danvers, MA, 7003) and bands were visualized on KODAK Biomax light film (Fisher Scientific). Densitometric analysis was performed using ImageJ software (National Institute of Health) and protein levels were normalized to GAPDH (sc-25778) (Santa Cruz Biotechnology Inc., Santa Cruz, CA) protein levels for each sample.

\section{Statistics}

Unless otherwise indicated, the comparison between groups for western blots was performed using a standard Student's $t$-test assuming equal variance among samples. A $p$-value of 0.05 was considered significant and data is expressed as mean \pm standard error of independent experiments.

\section{Additional material}

Additional file 1: Figure S1. Three biological replicates of the cellular proteome of (A) 184A1, (B) BT474 and (C) SKBR3 resolved on $7 \mathrm{~cm}$ IPG strip 4-7.

Additional file 2: Table S1. Identification summary of the differentially expressed proteins in 184A1-BT474 comparison showing the rank and score from two different algorithms used to search the protein database. Worksheet 2 shows the sequence coverage, peptide matches, number of mass values searched and the RMS error.
Additional file 3: Table S2. Identification summary of the differentially expressed proteins in 184A1-SKBR3 comparison showing the rank and score from two different algorithms used to search the protein database. Worksheet 2 shows the sequence coverage, peptide matches, number of mass values searched and the RMS error.

Additional file 4: Table S3. Summary of IPA generated networks for proteins differentially expressed in BT474 (four networks) and SKBR3 (five networks). Molecules in bold are the focus molecules associated with the dataset and the score is the $p$-value associated with the network.

\section{Acknowledgements}

This work was supported by grants from the National Science Foundation (CAREER 1053490 to DJK), the National Cancer Institute (R15CA132124 to DJK), and the National Institute of Allergy and Infectious Diseases (R56Al076221 to DJK). The content is solely the responsibility of the authors and does not necessarily represent the official views of the National Science Foundation, the National Cancer Institute, the National Institute of Allergy and Infectious Diseases, or the National Institutes of Health.

\section{Author details}

${ }^{1}$ Department of Chemical Engineering, College of Engineering and Mineral Resources, West Virginia University, Morgantown, WV 26506, USA. ${ }^{2}$ Department of Microbiology, Immunology and Cell Biology and Mary Babb Randolph Cancer Center, School of Medicine, West Virginia University, Morgantown, W 26506, USA.

\section{Authors' contributions}

YK was responsible for the 2-DE, MALDI-TOF MS, PMF, IPA analysis, and immunoblotting. DK conceived of the study, participated in its design, analyzed data and coordinated its execution. All authors drafted, read and approved the final manuscript.

\section{Competing interests}

The authors declare that they have no competing interests.

Received: 1 November 2011 Accepted: 22 February 2012 Published: 22 February 2012

\section{References}

1. Hanahan D, Weinberg RA: Hallmarks of cancer: the next generation. Cell 2011, 144:646-674.

2. Morange M: The field of cancer research: an indicator of present transformations in biology. Oncogene 2007, 26:7607-7610.

3. Hahn WC, Counter CM, Lundberg AS, Beijersbergen RL, Brooks MW, Weinberg RA: Creation of human tumour cells with defined genetic elements. Nature 1999, 400:464-468.

4. Stephens PJ, McBride DJ, Lin ML, Varela I, Pleasance ED, Simpson JT, Stebbings LA, Leroy C, Edkins S, Mudie L, Greenman CD, Jia M, Latimer C, Teague JW, Lau KW, Burton J, Quail MA, Swerdlow H, Churcher C, Natrajan R, Sieuwerts AM, Martens JW, Silver DP, Langerod A, Russnes HE, Foekens JA, Reis-Filho JS, van V, Richardson AL, Borresen-Dale AL, Campbell PJ, Futreal PA, Stratton MR: Complex landscapes of somatic rearrangement in human breast cancer genomes. Nature 2009, 462:1005-1010.

5. Greenman C, Stephens P, Smith R, Dalgliesh GL, Hunter C, Bignell G, Davies H, Teague J, Butler A, Stevens C, Edkins S, O'Meara S, Vastrik I, Schmidt EE, Avis T, Barthorpe S, Bhamra G, Buck G, Choudhury B, Clements J, Cole J, Dicks E, Forbes S, Gray K, Halliday K, Harrison R, Hills K, Hinton J, Jenkinson A, Jones D, Menzies A, Mironenko T, Perry J, Raine K, Richardson D, Shepherd R, Small A, Tofts C, Varian J, Webb T, West S, Widaa S, Yates A, Cahill DP, Louis DN, Goldstraw P, Nicholson AG, Brasseur F, Looijenga L, Weber BL, Chiew YE, DeFazio A, Greaves MF, Green AR, Campbell P, Birney E, Easton DF, Chenevix-Trench G, Tan MH, Khoo SK, Teh BT, Yuen ST, Leung SY, Wooster R, Futreal PA, Stratton MR: Patterns of somatic mutation in human cancer genomes. Nature 2007, 446:153-158.

6. Bild AH, Yao G, Chang JT, Wang Q, Potti A, Chasse D, Joshi MB, Harpole D, Lancaster JM, Berchuck A, Olson JA Jr, Marks JR, Dressman HK, West M, 
Nevins JR: Oncogenic pathway signatures in human cancers as a guide to targeted therapies. Nature 2006, 439:353-357.

7. Greaves M, Maley CC: Clonal evolution in cancer. Nature 2012, 481:306-313.

8. Gygi SP, Rochon Y, Franza BR, Aebersold R: Correlation between protein and mRNA abundance in yeast. Mol Cell Biol 1999, 19:1720-1730.

9. Kholodenko BN: Cell-signalling dynamics in time and space. Nat Rev Mol Cell Biol 2006, 7:165-176.

10. Cox J, Mann M: Is proteomics the new genomics? Cell 2007, 130:395-398.

11. Miles CM, Wayne M: Quantitative Trait Locus (QTL) analysis. Nature Education 2008, 1(1)[http://www.nature.com/scitable/topicpage/ quantitative-trait-locus-qtl-analysis-53904].

12. Patwardhan AJ, Strittmatter EF, Camp DG, Smith RD, Pallavicini MG: Quantitative proteome analysis of breast cancer cell lines using 180labeling and an accurate mass and time tag strategy. Proteomics 2006, 6:2903-2915.

13. Alexopoulos LG, Saez-Rodriguez J, Cosgrove BD, Lauffenburger DA, Sorger PK: Networks inferred from biochemical data reveal profound differences in toll-like receptor and inflammatory signaling between normal and transformed hepatocytes. Mol Cell Proteomics 2010, 9:1849-1865

14. Perou CM, Sorlie T, Eisen MB, van de RM, Jeffrey SS, Rees CA, Pollack JR, Ross DT, Johnsen $H$, Akslen LA, et al: Molecular portraits of human breast tumours. Nature 2000, 406:747-752.

15. Sorlie T, Perou CM, Tibshirani R, Aas T, Geisler S, Johnsen H, Hastie T, Eisen MB, van de RM, Jeffrey SS, et al: Gene expression patterns of breast carcinomas distinguish tumor subclasses with clinical implications. Proc Natl Acad Sci USA 2001, 98:10869-10874.

16. Sorlie T, Wang Y, Xiao C, Johnsen H, Naume B, Samaha RR, BorresenDale AL: Distinct molecular mechanisms underlying clinically relevant subtypes of breast cancer: gene expression analyses across three different platforms. BMC Genomics 2006, 7:127.

17. Sihto H, Lundin J, Lehtimaki T, Sarlomo-Rikala M, Butzow R, Holli K, Sailas L, Kataja V, Lundin M, Turpeenniemi-Hujanen T, et al: Molecular subtypes of breast cancers detected in mammography screening and outside of screening. Clin Cancer Res 2008, 14:4103-4110.

18. Onitilo AA, Engel JM, Greenlee RT, Mukesh BN: Breast cancer subtypes based on ER/PR and Her2 expression: comparison of clinicopathologic features and survival. Clin Med Res 2009, 7:4-13.

19. Huang DW, Sherman BT, Tan Q, Kir J, Liu D, Bryant D, Guo Y, Stephens R, Baseler MW, Lane HC, et al: DAVID Bioinformatics Resources: expanded annotation database and novel algorithms to better extract biology from large gene lists. Nucleic Acids Res 2007, 35:W169-W175.

20. Lasfargues EY, Coutinho WG, Redfield ES: Isolation of two human tumor epithelial cell lines from solid breast carcinomas. J Natl Canc Inst 1978, 61:961-978.

21. Trempe GL: Human breast cancer in culture. Recent Results Cancer Res 1976, 57:33-41.

22. Bhaskaran N, Lin KW, Gautier A, Woksepp H, Hellman U, Souchelnytskyi S: Comparative proteome profiling of MCF10A and 184A1 human breast epithelial cells emphasized involvement of CDK4 and cyclin D3 in cell proliferation. Proteomics Clin Appl 2009, 3:68-77.

23. Weinberg RA: The Biology of Cancer New York, NY: Garland Science; 2007.

24. Kulkarni YM, Suarez V, Klinke DJ: Inferring predominant pathways in cellular models of breast cancer using limited sample proteomic profiling. BMC Cancer 2010, 10:291.

25. Morali OG, Delmas V, Moore R, Jeanney C, Thiery JP, Larue L: IGF-II induces rapid beta-catenin relocation to the nucleus during epithelium to mesenchyme transition. Oncogene 2001, 20:4942-4950.

26. Mani SA, Guo W, Liao MJ, Eaton EN, Ayyanan A, Zhou AY, Brooks M, Reinhard F, Zhang CC, Shipitsin M, et al: The epithelial-mesenchymal transition generates cells with properties of stem cells. Cell 2008, 133:704-715.

27. Voulgari A, Pintzas A: Epithelial-mesenchymal transition in cancer metastasis: mechanisms, markers and strategies to overcome drug resistance in the clinic. Biochim Biophys Acta 2009, 1796:75-90.

28. Belfiore A, Malaguarnera R: Insulin receptor and cancer. Endocr Relat Cancer 2011, 18:R125-R147.

29. Klinke DJ: Signal transduction networks in cancer: quantitative parameters influence network topology. Cancer Res 2010, 70:1773-1782.
30. Kokai Y, Myers JN, Wada T, Brown VI, LeVea CM, Davis JG, Dobashi K, Greene MI: Synergistic interaction of p185c-neu and the EGF receptor leads to transformation of rodent fibroblasts. Cell 1989, 58:287-292.

31. Kawazoe $Y$, Nakai A, Tanabe M, Nagata K: Proteasome inhibition leads to the activation of all members of the heat-shock-factor family. Eur $J$ Biochem 1998, 255:356-362.

32. Bush KT, Goldberg AL, Nigam SK: Proteasome inhibition leads to a heatshock response, induction of endoplasmic reticulum chaperones, and thermotolerance. J Biol Chem 1997, 272:9086-9092.

33. Williams K, Chubb C, Huberman E, Giometti CS: Analysis of differential protein expression in normal and neoplastic human breast epithelial cell lines. Electrophoresis 1998, 19:333-343.

34. Franzen B, Linder S, Alaiya AA, Eriksson E, Fujioka K, Bergman AC, Jornvall H, Auer $\mathrm{G}$ : Analysis of polypeptide expression in benign and malignant human breast lesions. Electrophoresis 1997, 18:582-587.

35. Fernandez PM, Tabbara SO, Jacobs LK, Manning FC, Tsangaris TN, Schwartz AM, Kennedy KA, Patierno SR: Overexpression of the glucoseregulated stress gene GRP78 in malignant but not benign human breast lesions. Breast Cancer Res Treat 2000, 59:15-26.

36. Barazi HO, Zhou L, Templeton NS, Krutzsch HC, Roberts DD: Identification of heat shock protein 60 as a molecular mediator of alpha 3 beta integrin activation. Cancer Res 2002, 62:1541-1548.

37. Li DQ, Wang L, Fei F, Hou YF, Luo JM, Zeng R, Wu J, Lu JS, Di GH, Ou ZL, Xia QC, Shen ZZ, Shao ZM: Identification of breast cancer metastasisassociated proteins in an isogenic tumor metastasis model using twodimensional gel electrophoresis and liquid chromatography-ion trapmass spectrometry. Proteomics 2006, 6:3352-3368.

38. Johnstone RW, Frew AJ, Smyth MJ: The TRAIL apoptotic pathway in cancer onset, progression and therapy. Nat Rev Cancer 2008, 8:782-798.

39. Norbury CJ, Zhivotovsky B: DNA damage-induced apoptosis. Oncogene 2004, 23:2797-2808.

40. Pucci B, Kasten M, Giordano A: Cell cycle and apoptosis. Neoplasia 2000, 2:291-299.

41. Huang DC, Strasser A: BH3-Only proteins-essential initiators of apoptotic cell death. Cell 2000, 103:839-842

42. Chen L, Willis SN, Wei A, Smith BJ, Fletcher Jl, Hinds MG, Colman PM Day CL, Adams JM, Huang DC: Differential targeting of prosurvival $\mathrm{BCl}-2$ proteins by their $\mathrm{BH} 3$-only ligands allows complementary apoptotic function. Mol Cell 2005, 17:393-403.

43. Oltersdorf T, Elmore SW, Shoemaker AR, Armstrong RC, Augeri DJ, Belli BA, Bruncko M, Deckwerth TL, Dinges J, Hajduk PJ, Joseph MK, Kitada S, Korsmeyer SJ, Kunzer AR, Letai A, Li C, Mitten MJ, Nettesheim DG, Ng S, Nimmer PM, O'Connor JM, Oleksijew A, Petros AM, Reed JC, Shen W, Tahir SK, Thompson CB, Tomaselli KJ, Wang B, Wendt MD, Zhang H, Fesik SW, Rosenberg SH: An inhibitor of $\mathrm{Bcl}-2$ family proteins induces regression of solid tumours. Nature 2005, 435:677-681.

44. Walensky LD, Kung AL, Escher I, Malia TJ, Barbuto S, Wright RD, Wagner G, Verdine GL, Korsmeyer SJ: Activation of apoptosis in vivo by a hydrocarbon-stapled BH3 helix. Science 2004, 305:1466-1470.

45. Disson O, Haouzi D, Desagher S, Loesch K, Hahne M, Kremer EJ, Jacquet C, Lemon SM, Hibner U, Lerat $\mathrm{H}$ : Impaired clearance of virus-infected hepatocytes in transgenic mice expressing the hepatitis $C$ virus polyprotein. Gastroenterology 2004, 126:859-872.

46. Amm HM, Zhou T, Steg AD, Kuo H, Li Y, Buchsbaum DJ: Mechanisms of drug sensitization to TRA-8, an agonistic death receptor 5 antibody, involve modulation of the intrinsic apoptotic pathway in human breast cancer cells. Mol Cancer Res 2011, 9:403-417

47. Purcell JW, Davis J, Reddy M, Martin S, Samayoa K, Vo H, Thomsen K, Bean P, Kuo WL, Ziyad S, Billig J, Feiler HS, Gray JW, Wood KW, Cases S: Activity of the kinesin spindle protein inhibitor ispinesib (SB-715992) in models of breast cancer. Clin Cancer Res 2010, 16:566-576.

48. Goll DE, Thompson VF, Li H, Wei W, Cong J: The calpain system. Physio Rev 2003, 83:731-801.

49. Chhabra A, Fernando $H$, Mansel RE, Jiang WG: Pattern of expression of calpain subunits (large and small) in human breast cancer and the prognostic significance. ASCO Annual Meeting Proceedings 2007, 25(18S):6-20.

50. Kubbutat $\mathrm{MH}$, Vousden $\mathrm{KH}$ : Proteolytic cleavage of human p53 by calpain: a potential regulator of protein stability. Mol Cell Biol 1997, 17:460-468. 
51. Han Y, Weinman S, Boldogh I, Walker RK, Brasier AR: Tumor necrosis factoralpha-inducible IkappaBalpha proteolysis mediated by cytosolic $\mathrm{m}$ calpain. A mechanism parallel to the ubiquitin-proteasome pathway for nuclear factor-kappab activation. J Biol Chem 1999, 274:787-794.

52. Zhu H, Zhang L, Huang X, Davis JJ, Jacob DA, Teraishi F, Chiao P, Fang B: Overcoming acquired resistance to TRAIL by chemotherapeutic agents and calpain inhibitor I through distinct mechanisms. Mol Ther 2004, 9:666-673.

53. Mlynarczuk-Bialy I, Roeckmann H, Kuckelkorn U, Schmidt B, Umbreen S, Golab J, Ludwig A, Montag C, Wiebusch L, Hagemeier C, Schadendorf D, Kloetzel PM, Seifert U: Combined effect of proteasome and calpain inhibition on cisplatin-resistant human melanoma cells. Cancer Res 2006, 66:7598-7605.

54. Kulkarni S, Reddy KB, Esteva FJ, Moore HC, Budd GT, Tubbs RR: Calpain regulates sensitivity to trastuzumab and survival in HER2-positive breast cancer. Oncogene 2010, 29:1339-1350.

55. Simonin $Y$, Disson O, Lerat $H$, Antoine E, Biname F, Rosenberg AR, Desagher S, Lassus P, Bioulac-Sage P, Hibner U: Calpain activation by hepatitis $C$ virus proteins inhibits the extrinsic apoptotic signaling pathway. Hepatology 2009, 50:1370-1379.

56. Van Antwerp DJ, Martin SJ, Kafri T, Green DR, Verma IM: Suppression of TNF-alpha-induced apoptosis by NF-kappaB. Science 1996, 274:787-789.

57. Sovak MA, Bellas RE, Kim DW, Zanieski GJ, Rogers AE, Traish AM, Sonenshein GE: Aberrant nuclear factor-kappaB/Rel expression and the pathogenesis of breast cancer. J Clin Invest 1997, 100:2952-2960.

58. Wang CY, Cusack JC Jr, Liu R, Baldwin AS Jr: Control of inducible chemoresistance: enhanced anti-tumor therapy through increased apoptosis by inhibition of NF-kappaB. Nat Med 1999, 5:412-417.

59. Garg A, Aggarwal BB: Nuclear transcription factor-kappaB as a target for cancer drug development. Leukemia 2002, 16:1053-1068.

60. Bateman NW, Sun M, Hood BL, Flint MS, Conrads TP: Defining central themes in breast cancer biology by differential proteomics: conserved regulation of cell spreading and focal adhesion kinase. $J$ Proteome Res 2010, 9:5311-5324.

61. Benjamini Y, Hochberg Y: Controlling the False Discovery Rate: A Practical and Powerful Approach to Multiple Testing. J Royal Stat Soc Series B (Methodological) 1995, 57(1):289-300.

62. Huang DW, Sherman BT, Lempicki RA: Systematic and integrative analysis of large gene lists using DAVID bioinformatics resources. Nat Protoc 2009, 4:44-57.

63. Huang DW, Sherman BT, Lempicki RA: Bioinformatics enrichment tools: paths toward the comprehensive functional analysis of large gene lists. Nucleic Acids Res 2009, 37:1-13.

doi:10.1186/1477-5956-10-11

Cite this article as: Kulkarni and Klinke: Protein-based identification of quantitative trait loci associated with malignant transformation in two HER2+ cellular models of breast cancer. Proteome Science 2012 10:11.

\section{Submit your next manuscript to BioMed Central and take full advantage of:}

- Convenient online submission

- Thorough peer review

- No space constraints or color figure charges

- Immediate publication on acceptance

- Inclusion in PubMed, CAS, Scopus and Google Scholar

- Research which is freely available for redistribution 